\title{
Analysis of Innovative Ways of Educational Administration in Private Colleges
}

\author{
Si-yi LI \\ Xijing University, Xi'an, Shaanxi, China
}

Keywords: Private University; Educational Administration; Innovation Capability.

\begin{abstract}
With the deepening of the popularization of higher education, the competition between college students is becoming increasingly fierce, opportunities and challenges coexist, private colleges should take this opportunity to improve the quality of education and teaching. However, the improvement of teaching quality can not be separated from scientific and effective educational administration. In view of the current situation of the management of private colleges and universities, this paper puts forward some suggestions on strengthening the educational administration of private colleges from two aspects of school leadership and educational administration.
\end{abstract}

\section{Introduction}

With the popularization of higher education, the scale of running school is expanding rapidly, the levels and types of running school are becoming more and more diversified, which puts forward higher demands on educational administration work. In order to survive and develop in the fierce competition, it is necessary to raise, reform and innovate the educational administration work in the similar colleges.

\section{Status Quo of Educational Administration in Private Universities}

\subsection{The quality of academic management personnel is not high}

At present, with the increase of enrollment in private universities, there have been many "million people" colleges and universities, the scale of the school has gradually expanded, the number of administrative posts in colleges and universities lags far behind the scale of the school's growth rate. In the administrative positions of private colleges and universities, the educational administration staff is generally less, mainly because of the busy work, responsibility and complexity of the work of the educational administration department and the job specifying. As a result of the development of private colleges and universities, each administrative officer is engaged in a number of jobs, all day in the complex management affairs, tired of coping and mechanical work, no energy to work enthusiasm and innovative ideas. Second, the educational administration staffs pay far less than other positions. Private schools generally attach importance to the status of teachers and students, that teachers can produce results, out of the bright spots, thus improving school grade and increasing visibility. In order to stabilize the teaching staff, the teachers' research salary and scientific research supporting funds are much higher than the public schools at the expense of employing well-known scholars and professors. In contrast, the educational administration personnel can only get the very low administrative position salary, and the main reason is that leaders do not attach enough importance to teaching administrators. The main service object of educational administration department is teacher, but because of the big salary gap, it is easy to produce inferiority complex, which leads to the lack of service consciousness.

\subsection{The structure of teaching management team is unreasonable}

\subsubsection{Teaching management staff academic level and professional background are uneven}

In the private colleges and universities engaged in grass-roots work of the educational management personnel, education background is mostly non-educational management professional 
undergraduates, these people lack professional knowledge in education, management, psychology and other aspects, are accustomed to follow instructions, documents, experience, lack of innovative spirit.

\subsubsection{The discrepancy between age and title structure of teaching management staff}

The age proportion of teaching management team is: the proportion of young people is high, and the proportion of middle-aged people is low; title structure: the proportion of primary titles is high, and the proportion of senior titles is low.

\subsection{Teaching leaders' outdated teaching concepts}

The university leaders generally do not attach importance to educational administration, especially in private universities. The leader mistakenly thinks that the educational administration is a regular transactional work, far less than scientific research can produce results, underestimating the role of educational administration department, considered "No is Work". The wrong idea causes the educational administration personnel to lack the training, the study, and then raises the opportunity, cannot form the effective innovation mechanism. Specific performance in the academic management staff enthusiasm is more than the phenomenon, too stressed the normative and service-oriented work, more attention to normative operations, normative management, encountered emergency events lack of flexibility, flexible treatment, lack of predictability of events, lack of innovation awareness training. The teaching management mode is rigid, blindly relying on the experience management to occupy the leading position, and the educational administration process is slow, affecting the work efficiency.

Facing the current situation of educational administration, how can we break free from embarrassment and move towards the road? We need to manage innovation, the revolution of management. The innovation of educational administration management is to change the management work mode fundamentally, eliminate the malpractice of management, and finally promote the realization of organizational goals. Management innovation is a systematic process, not overnight, to develop medium and long-term planning, the process of innovation is not smooth sailing, the middle will experience repeated twists and turns, to firmly believe that continuous innovation in practice will eventually change over time and achieve the expected success of innovation.

\section{Innovative Ideas of University Educational Administration Management}

\subsection{School Leadership}

\subsubsection{Change old ideas and make development plans}

Teaching management is the core part of stabilizing teaching order and improving teaching quality. Educational administration is the embodiment of teaching management and an important part of teaching management [1]. The essence of educational administration is to create a good teaching atmosphere, mobilize the students and staff to complete the established teaching objectives efficiently, ensure the teaching quality, and train qualified personnel [2]. School leaders should pay attention to the important role of teaching management, and fully realize that the construction of high-quality, high-level and efficient educational administration team is of great significance to improve teaching quality. It is a medium-and long-term development plan to improve the educational administration team to construct a teaching administration team with its own management characteristics.

\subsubsection{Pay attention to skill training and rationally optimize the administration team}

Private colleges and universities actively create conditions for teaching managers to visit the management process of some famous schools, learn from the theory of learning management, experience; invite educational administration experts to give lectures, impart experience, and provide opportunities for teaching management staff training; encourage teaching managers to upgrade their academic qualifications and further study; improve the remuneration of educational 
administration staff, as far as possible to narrow the gap between teachers and create a harmonious work environment, so that the educational management staff gradually into the school culture, with a sense of belonging, dedication, so as to stabilize the teaching management team.

Private colleges and universities in the selection of administrative personnel to implement a strict access system, in order to open recruitment and organizational internal combination of principles, select high-educated, high-quality education, professional background, or strong management ability, teaching and research experience of talent to join the teaching management team. The flexible employing mechanism of the fittest is used by the private universities to streamline the diversion of managers who have poor sense of responsibility, weak business ability and poor innovation ability; focus on training the managers with innovative spirit, strong sense of responsibility, so that they play an important role in the post.

\subsubsection{Set up characteristic educational administration system}

The core competitiveness of private colleges and universities is characteristic, the characteristic of running a school is the lifeline of private university, and the implementation of school management mode makes the administration of private colleges more complicated [3]. It is urgent to develop a practical educational administration system that conforms to its own characteristics. The perfect rules and regulations not only can provide the system guarantee for the educational administration, but also can standardize the work procedure of the academic staff. In a sense, the educational administration is a periodical, repetitive standardization work. In a sense, the educational administration is a periodical, repetitive standardization work. Private colleges and universities can use the advantages of privately-run schools, flexibly learn from the practice of enterprise standardization, and strive to institutionalize and standardize the administration of education, to form a standardized management model, thus reducing the personal quality of the academic personnel and subjective randomness of the impact of management work, to ensure that the work according to the procedure, can greatly improve the working efficiency

\subsubsection{Promote the modernization of university educational administration means}

In the daily administration of university education, involving all kinds of data information is very large, all kinds of data is in a dynamic process, which will cause a great deal of work to the administration. Therefore, it is necessary to innovate the management technology, make use of the mature computer management system to play an auxiliary role in educational administration, realize the sharing of teaching resources of the whole school and departments, and realize the paperless and network of educational administration gradually. For the educational administration to provide efficient, stable and coordinated technical support, and then make the academic work more scientific, standardized, and programmatic.

\subsection{Personal level of educational administration}

The cultivation of innovation quality of educational administration personnel strengthens the study of educational management theory. The educational administration personnel should not only understand the management related knowledge, but also learn the education theory and understand the teaching law, in order to follow the development rules of education, so that the teaching work orderly operation.

\subsubsection{Pay attention to the cultivation of scientific research ability}

The scientific research ability refers to the educational administration personnel to use the knowledge to the management idea, the method and the content unceasing ponder, the inquiry. The training of scientific research ability can summarize the experience of educational administration and provide reference for future work. Absorbing the advanced concept and drawing the improvement plan; from the perspective of management, explore the forward-looking issues.

\subsubsection{Strengthen the management ability training of academic staff}

The academic staff should have good communication and coordination ability, the ability to use modern management, the ability to co-ordinate arrangements, to make the academic work from announce to implementation, laws and objectives are unified. 


\subsubsection{Familiar with business processes and improves business capabilities}

Private colleges and universities combine their own characteristics, forming a set of effective management rules and regulations, to be familiar with the process, skilled use of practical work, to avoid the principle of error, to ensure efficient and high quality to complete the work. Abandon according to instructions, documents, experience work style, to be diligent in thinking, more research, with management knowledge to guide the actual work.

\subsubsection{Build people-oriented service concept and strengthening service consciousness}

The object of teaching management is the teacher and the student, which plays an important role in service teaching and connection training. Therefore, the educational administration needs adhering to the management idea of "communication", "coordination" and "service", emphasizing the management method of "participatory" and "inspiring", and constructing the new educational administration system of "people-oriented" [4]. The service object is students, consider the individual differences of students, to stand in the student position for their sake, and actively solve the matter. Service objects are teachers, especially part-time teachers, to be meticulous and thoughtful, school management rules and regulations communicated to the teacher, schedule when the priority to consider part-time, meet the school notice, timely communicated to the teacher.

\section{Conclusion}

With the increasing competition of college students, it is necessary to improve the teaching quality and enhance the characteristics of the school to become our new task and challenge. To give full play to the advantages of running schools and to do well in teaching management, private colleges and universities depend on training a group of excellent teaching management personnel.

\section{References}

[1] Liu Jianqing. Research on Educational Administration in Colleges and Universities [D]. Wuhan: Master's thesis of Huazhong Normal University, 2009

[2] Xu Chengxu. Research on the Construction of Teaching Management Team in Private Colleges and Universities [J]. Journal of Jilin Radio and Television University. 2012 (1).

[3] Li Zhaodi. A Brief Discussion on the Educational Administration of Private Colleges and Universities [J]. Science Management. 2013 (42).

[4] Zhang Qun. Innovation of Educational Administration Management Based on Humanistic Management Concept [J]. Journal of China Youth University for Political Sciences. 2012 (6). 